\title{
A Synthetic Vesicle-to-Vesicle Communication System
}

Yudi Ding, ${ }^{a}$ Nicholas H. Williams ${ }^{b}$ and Christopher A. Hunter ${ }^{a *}$

a Department of Chemistry, University of Cambridge, Lensfield Road, Cambridge CB2 1EW, United Kingdom

bepartment of Chemistry, University of Sheffield, Sheffield S3 7HF, United Kingdom

\section{Supporting information}

\section{Content}

1. Molecular modelling

2. Synthetic procedures and characterization

3. Vesicle experiments

4. References 


\section{Molecular modelling}

There is no NeutrAvidin•biotin crystal structure available in the PDB bank, so the X-ray crystal structure of the avidin•biotin complex (PDB entry: 2AVI) was used to assess an appropriate length of linker to ensure that the membrane would not interfere with binding. NeutrAvidin is a deglycosylated version of avidin. The structure of the transducer 1 was built and energy minimized in an extended conformation using Avogadro. The amide group of the linker unit of transducer 1 was superimposed with the carboxylate group of biotin in the binding pocket of avidin using VMD (Figure S1). The dihedral angle adjustment function was used to manually configurate the bond angles of the rest of the transducer so that the steroid core extended towards outside of the protein. The resulting structure suggests that the linker used in transducer $\mathbf{1}$ is long enough to allow protein binding to the dethiobiotin unit simultaneously with anchoring of the steroid in the lipid bilayer of vesicles (Figure S2).

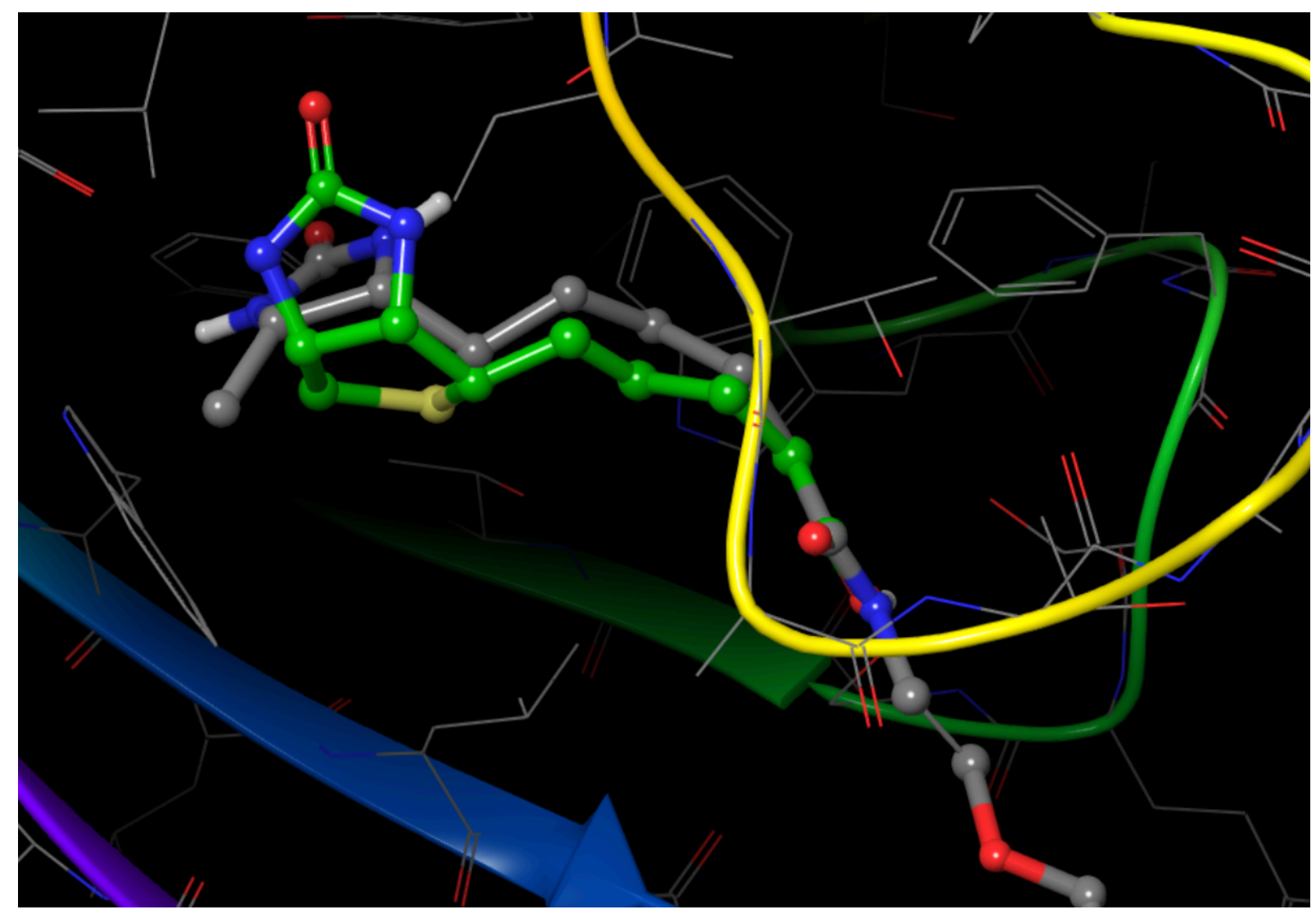

Figure S1 The binding pocket of the Avidin॰1 model. The amide group of the linker of $\mathbf{1}$ was superimposed with the carboxylate group of biotin in the binding pocket of avidin. 


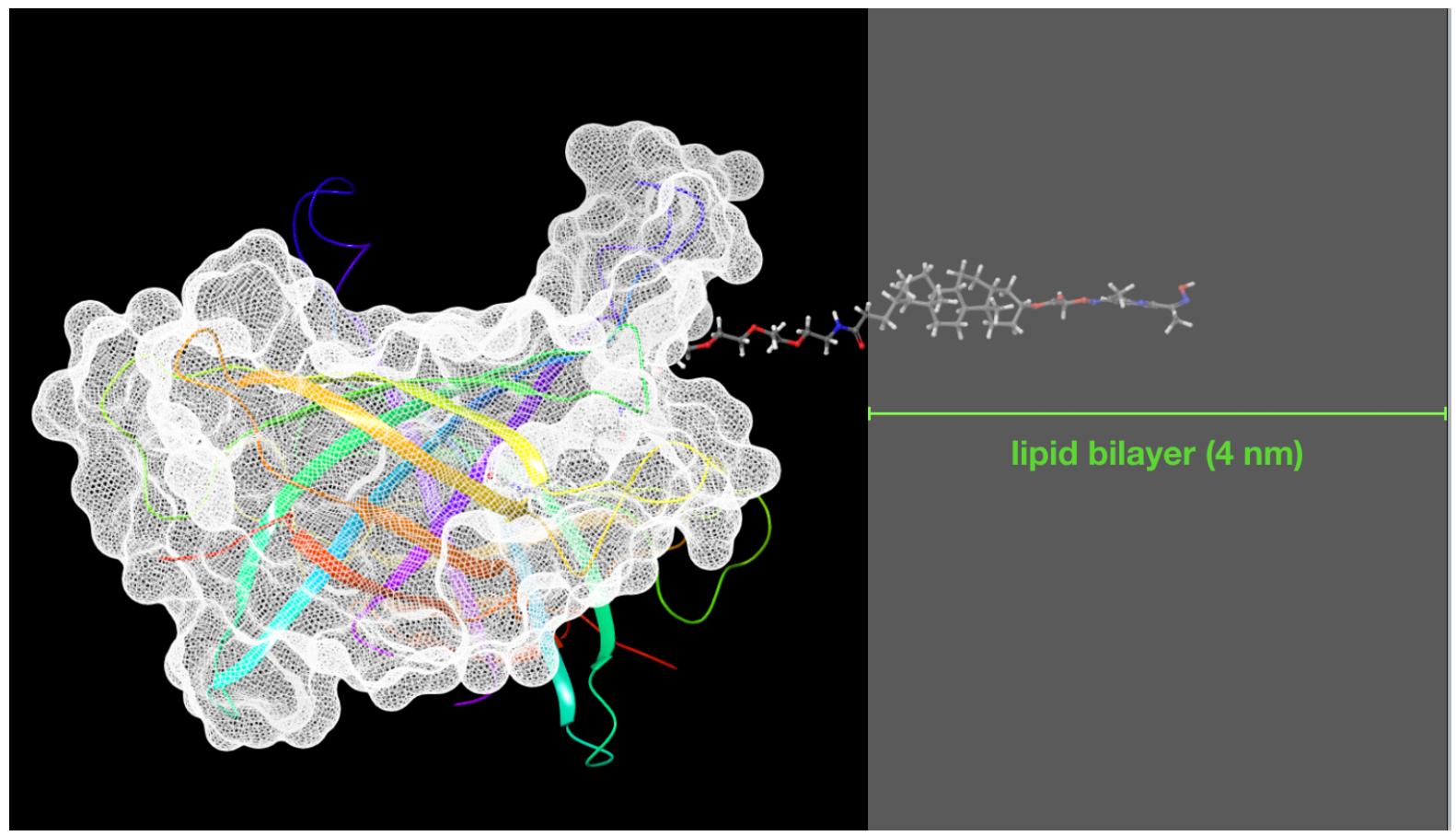

Fig. S2. Model of the Avidin•1 complex at a DOPC/DOPE lipid bilayer interface, which is $4 \mathrm{~nm}$ thick. ${ }^{1}$

\section{Synthetic procedures and characterizations.}

\section{Materials and Methods}

${ }^{1} \mathrm{H}$ NMR and ${ }^{13} \mathrm{C}$ NMR spectra were recorded on a 400-MHz Bruker ${ }^{\circledast}$ spectrometer. Chemical shifts are reported as $\delta$ values in ppm. Flash chromatography was carried out on an automated system

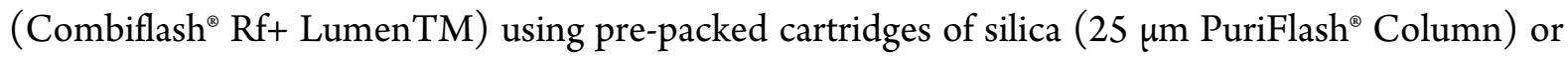
neutral alumina ( $50 \mu \mathrm{m}$ RediSep ${ }^{\circledast}$ Rf Column). GPC purification of the vesicles was carried out using GE Healthcare PD-10 desalting columns prepacked with Sephadex ${ }^{\otimes}$ G-25 medium. Fluorescence spectra were recorded using a Cary Eclipse fluorescence spectrophotometer (Agilent Technologies) in Hellma ${ }^{\circledR}$ Analytics Suprasil ${ }^{\circledR}$ quartz cuvettes. $\mathrm{pH}$ measurements were conducted using a MettlerToledo SevenCompactTM pH meter equipped with an InLab ${ }^{\circledast}$ Micro electrode. Vesicles were assembled in Eppendorf ${ }^{\oplus}$ polypropylene Protein LoBind ${ }^{\circledR}$ polypropylene microcentrifuge tube and extruded as described below using Avanti $^{\circledast}$ Polar Lipids extruder kits, equipped with Avestin ${ }^{\circledast}$ LiposoFast Liposome Factory $200 \mathrm{~nm}$ polycarbonate membranes with GE Healthcare Whatman ${ }^{\circledast} 10$ $\mathrm{mm}$ polyester filter support. Solutions or vesicles suspensions were transferred using Eppendorf Multipette $^{\circledast}$ Xstream Pippette with Combitips Advanced $^{\circledast}$ or Hamilton Microliter ${ }^{\mathrm{Tn}}$ syringes. All 
reagents and solvents were used without further purification. Chemicals were purchased from SigmaAldrich $^{\circledast}$ and used without further purification.

\section{Synthetic Procedures}

Scheme S1. Synthesis of desthiobiotin transducer 1.

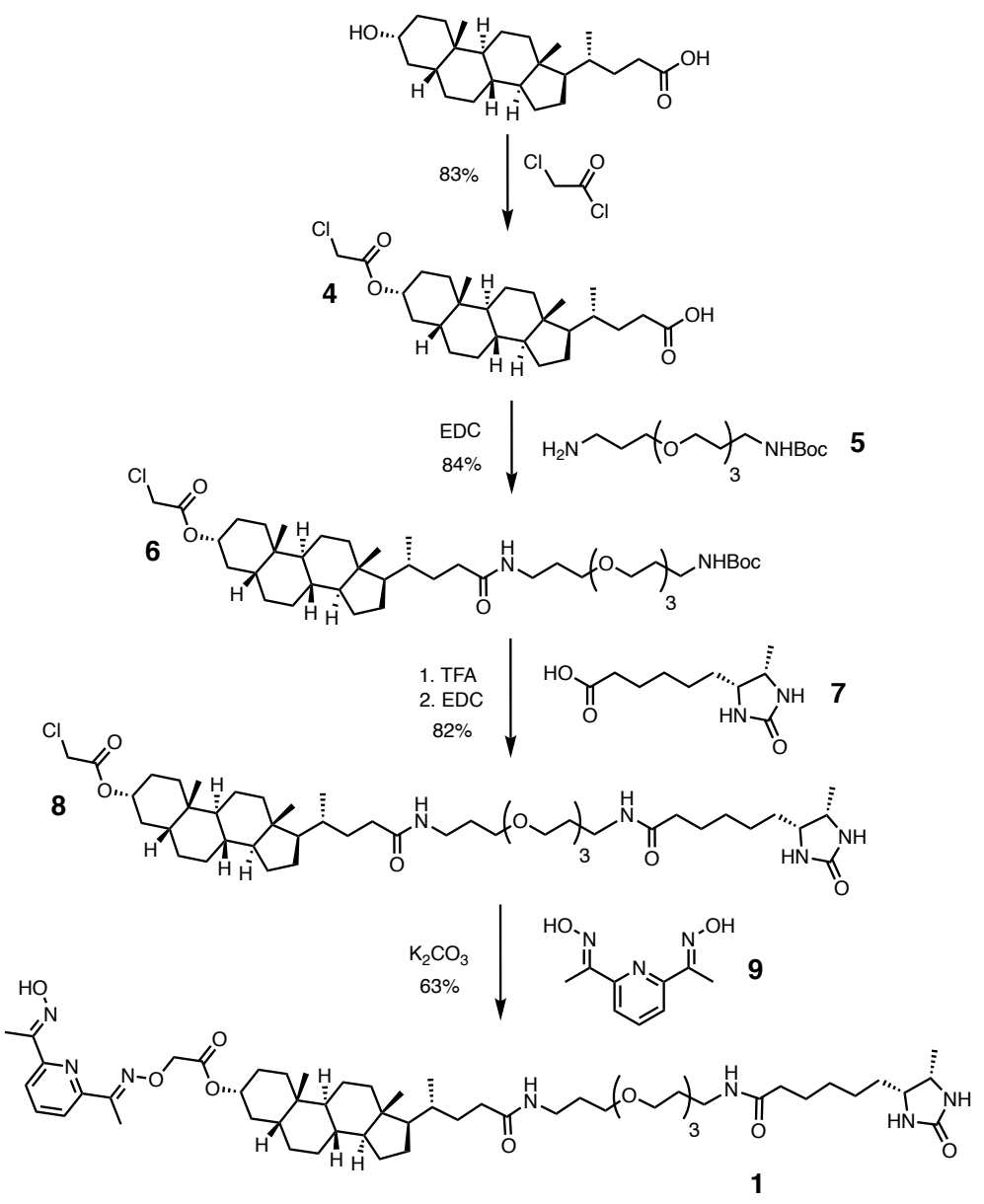

Scheme S2. Synthesis of ester substrate 2.

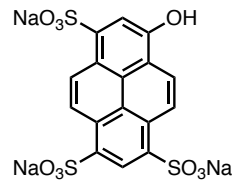

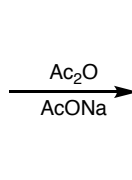

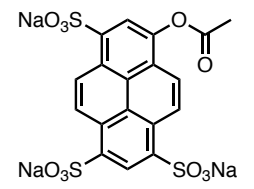

2 
Scheme S3. Synthesis of pyridine-dioxime 9.

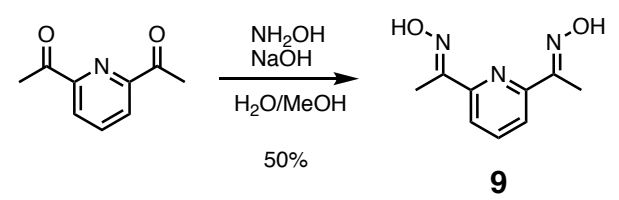

Scheme S4. Synthesis of biotin derivative 10.

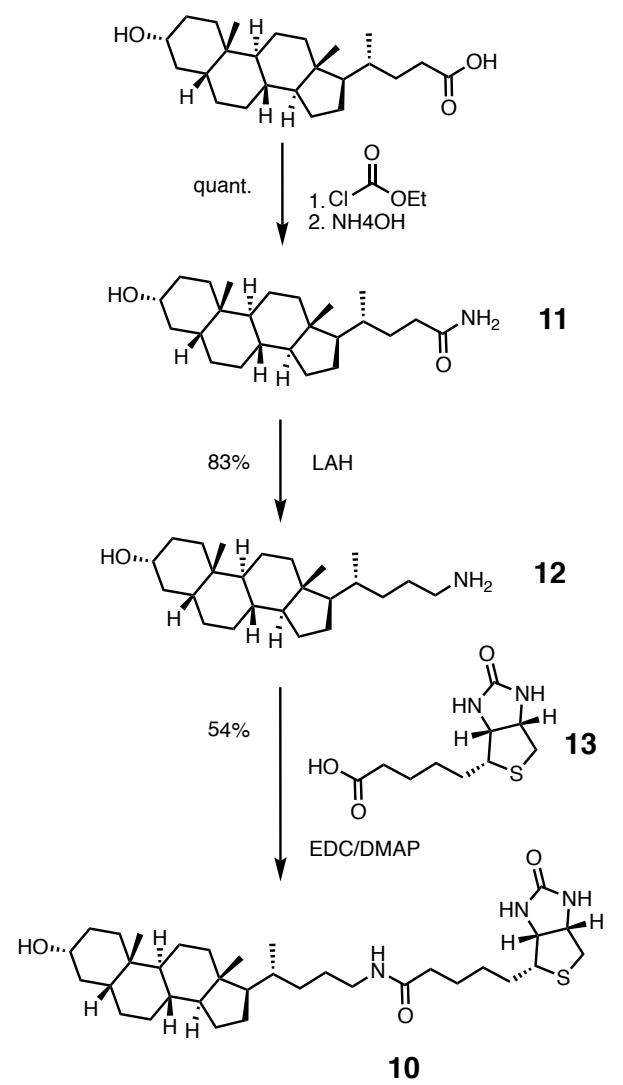


Compound 4

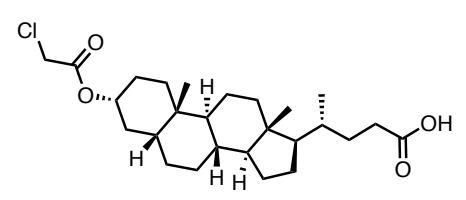

To a solution of lithocholic acid (1.0 g, $2.655 \mathrm{mmol})$ in tetrahydrofuran (20 mL) was added chloroacetyl chloride $(0.6 \mathrm{~g}, 5.311 \mathrm{mmol})$ with external cooling. The reaction mixture was stirred over night at room temperature. After the reaction was quenched by methanol ( $2 \mathrm{~mL}$ ) with external cooling, the solvent was removed in vacuo. The crude was purified by flash chromatography (silica, methanol in dichloromethane: 0 - 20\%) to yield a white solid (1.05 g, 83\%). ${ }^{1} \mathrm{H}$ NMR (400 MHz, $\left.\mathrm{CDCl}_{3}\right) \delta(\mathrm{ppm}): 4.81(\mathrm{~m}, 1 \mathrm{H}), 4.03(\mathrm{~s}, 2 \mathrm{H})$, $2.42-2.22(\mathrm{~m}, 2 \mathrm{H}), 1.98-0.91(\mathrm{~m}, 32 \mathrm{H}), 0.65(\mathrm{~s}, 3 \mathrm{H}) .{ }^{13} \mathrm{C} \mathrm{NMR}\left(100 \mathrm{MHz}, \mathrm{CDCl}_{3}\right) \delta(\mathrm{ppm})$ : 180.5, 167.0 56.6, 56.1, 42.9, 42.0, 41.4, 40.6, 40.2, 35.9, 35.1, 34.7, 32.2, 31.1, 30.9, 28.3, 27.1, 26.6, 26.4, 24.3, 23.4, 21.0, 18.4, 12.2.

HR-MS (ES+) calcd. for $\mathrm{C}_{26} \mathrm{H}_{41}{ }^{35} \mathrm{ClO}_{4}: 452.2693$, found 452.2690. FT-IR (ATR): $v_{\max }$ 2957, 2927, $2903,2866,2847,1750,1700 \mathrm{~cm}^{-1}$. 


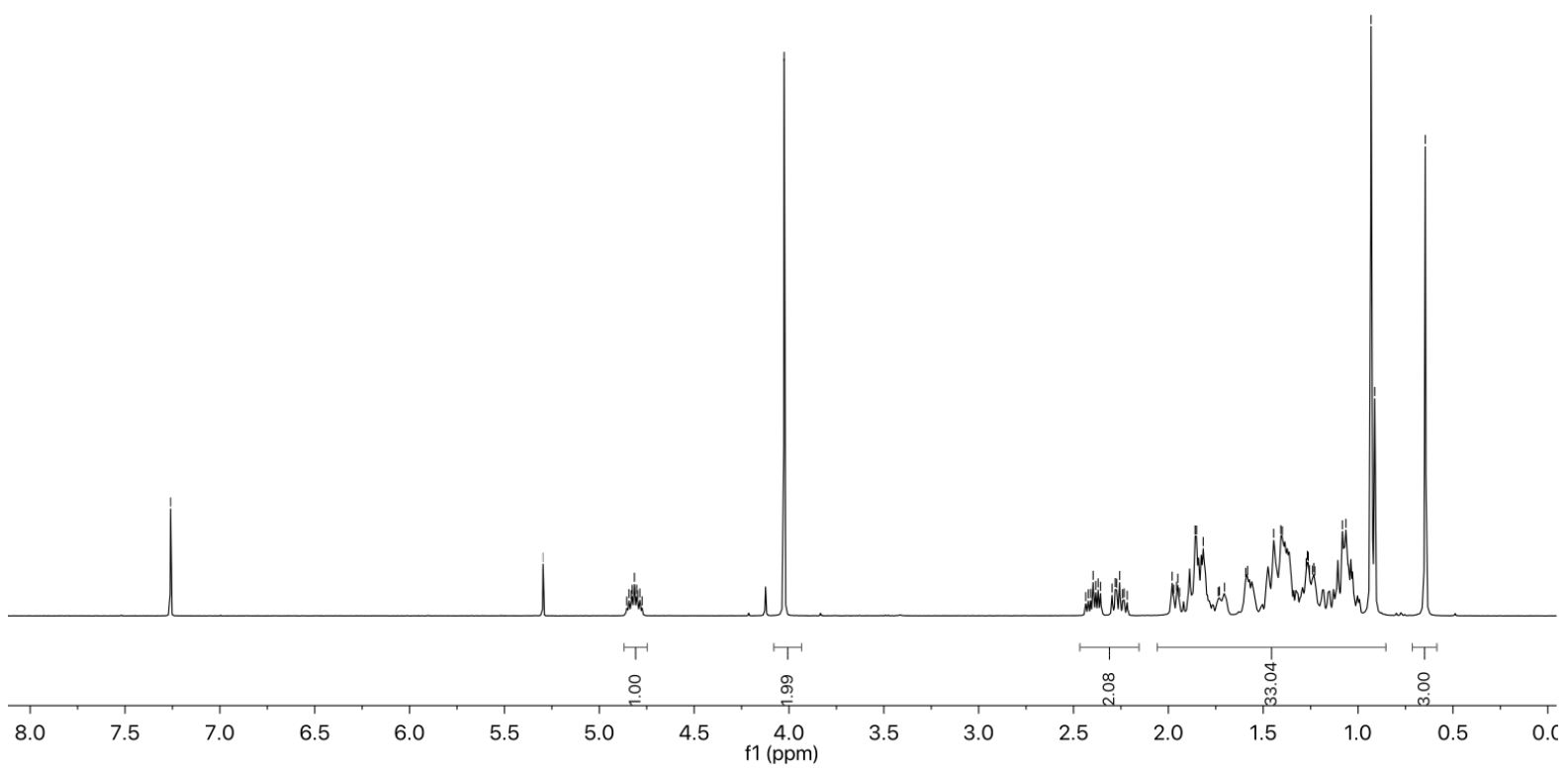

Figure S3. ${ }^{1} \mathrm{H}$ NMR spectrum of compound 4.

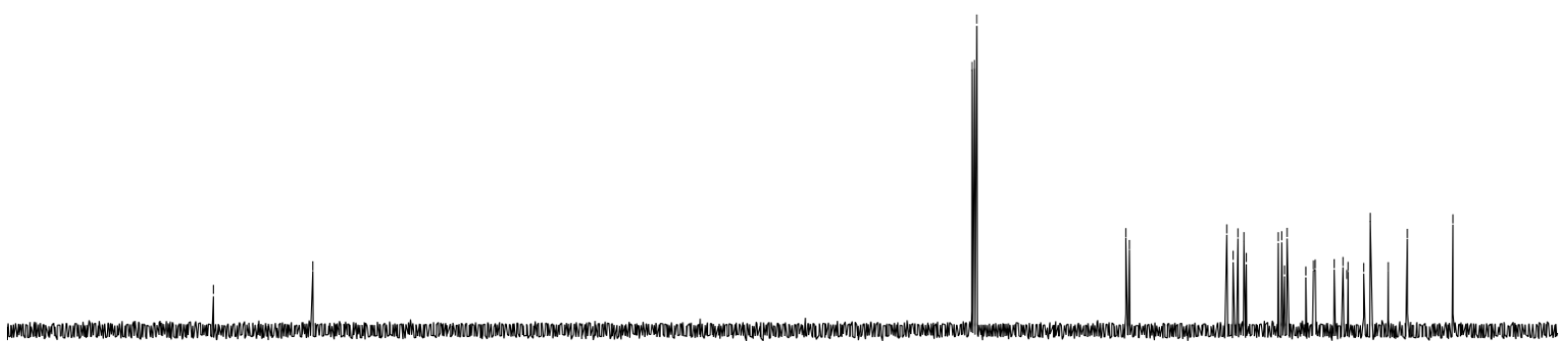

Figure S4. ${ }^{13} \mathrm{C}$ NMR spectrum of compound 4 . 
Compound 6

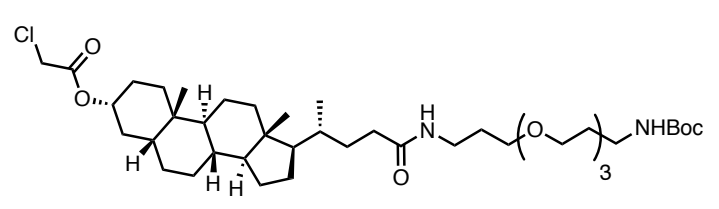

A mixture of compound 4 (100 mg, 0.221 mmol), N-Boc-4,7,10-trioxa-1,13tridecanediamine 5 (71 $\mathrm{mg}, 0.221 \mathrm{mmol})$, EDC (52 $\mathrm{mg}, 0.265 \mathrm{mmol}$ ) and 4dimethylaminopyridine (1 mg, cat.) in $3 \mathrm{~mL}$ of dichloromethane was stirred at room temperature overnight. The reaction mixture was diluted with $25 \mathrm{~mL}$ of dichloromethane, then washed with $1 \mathrm{M}$ hydrochloric acid (10 $\mathrm{mL} \times 2$ ), sodium bicarbonate (sat., $10 \mathrm{~mL}$ ), brine $(10 \mathrm{~mL})$ and dried over anhydrous sodium sulfate. The solvent was removed in vacuo and the crude was purified by flash chromatography (neutral alumina, methanol in dichloromethane $0-5 \%)$ to afford the product as a colorless oil $(140 \mathrm{mg}, 84 \%)$. ${ }^{1} \mathrm{H}$ $\operatorname{NMR}\left(400 \mathrm{MHz}, \mathrm{CDCl}_{3}\right) \delta(\mathrm{ppm}): 6.11(\mathrm{~s}, 1 \mathrm{H}), 4.94(\mathrm{~s}, 1 \mathrm{H}), 4.81(\mathrm{~m}, 1 \mathrm{H}), 4.03(\mathrm{~s}, 2 \mathrm{H}), 3.66-3.53$ $(\mathrm{m}, 13 \mathrm{H}), 3.38-3.23(\mathrm{~m}, 2 \mathrm{H}), 3.21-3.20(\mathrm{~m}, 2 \mathrm{H}), 2.25-2.17(\mathrm{~m}, 2 \mathrm{H}), 1.77-0.90(\mathrm{~m}, 43 \mathrm{H}), 0.62$ (s, 3H). ${ }^{13} \mathrm{C} \mathrm{NMR}\left(100 \mathrm{MHz}, \mathrm{CDCl}_{3}\right) \delta(\mathrm{ppm}): 173.4,166.8,156.0,77.2,70.5,70.5,70.2,70.1,69.6$, 56.4, 56.1, 42.7, 41.9, 41.2, 40.4, 40.1, 37.9, 37.5, 35.7, 35.5, 34.9, 34.5, 33.7, 32.0, 31.9, 31.8, 29.7, 29.0, $28.4,28.2,26.9,26.9,26.4,26.3,24.1,23.2,22.8,22.5,20.8,18.4,12.0$.

HR-MS (ES+): calcd. for $\mathrm{C}_{41} \mathrm{H}_{71} \mathrm{~N}_{2} \mathrm{O}_{8}{ }^{35} \mathrm{Cl}^{23} \mathrm{Na} 777.4785$, found 777.4791. FT-IR (ATR): $v_{\max } 3341$, $2936,2866,1711,1653,1526,1449,1364,1276,1252,1174 \mathrm{~cm}^{-1}$. 


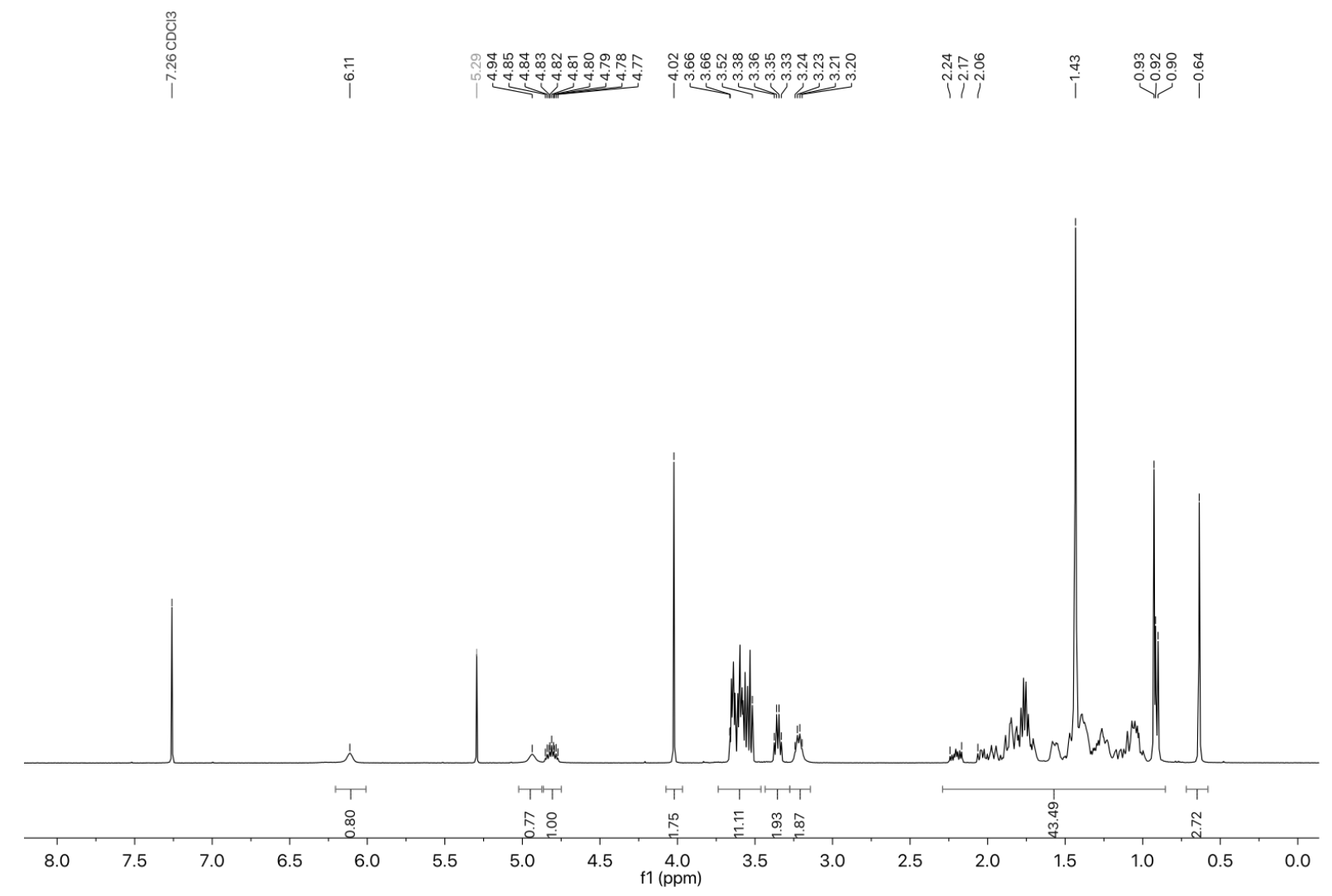

Figure S5. ${ }^{1} \mathrm{H}$ NMR spectrum of compound 6.

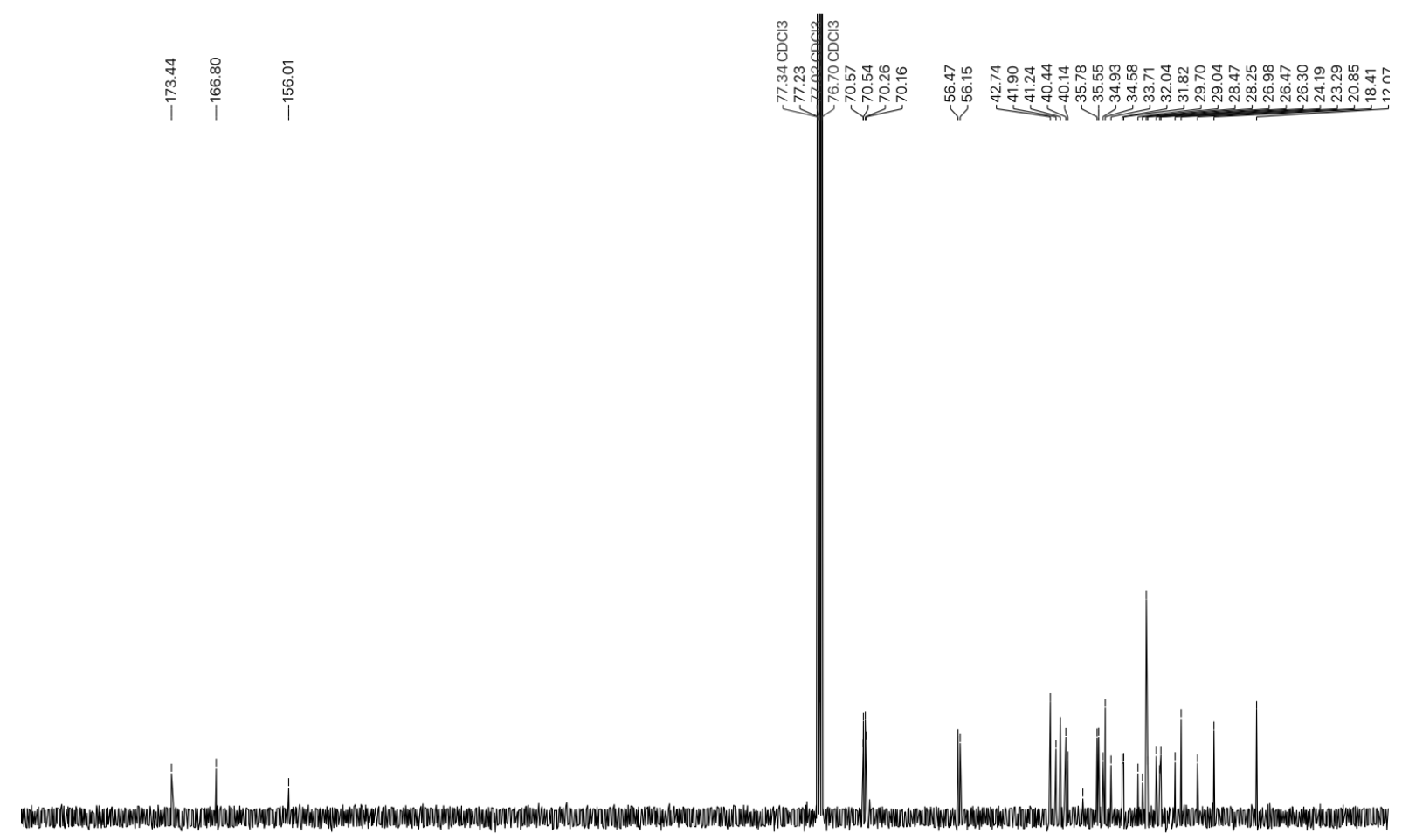

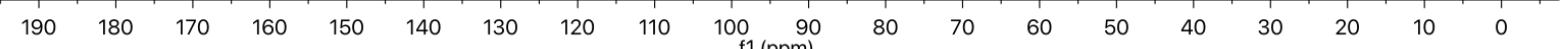

Figure S6. ${ }^{13} \mathrm{C}$ NMR spectrum of compound 6. 


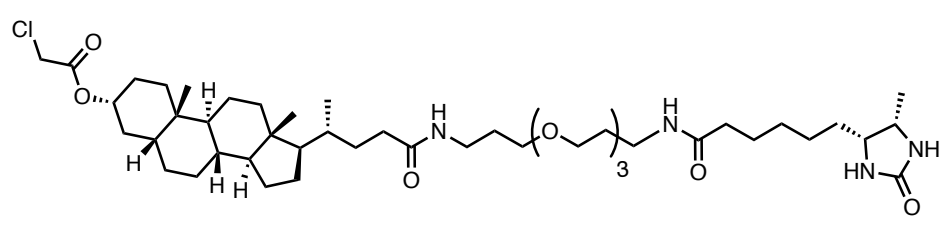

A solution of compound 6 (100 mg, $0.132 \mathrm{mmol})$ and $1 \mathrm{~mL}$ of trifluoroacetic acid in dichloromethane $(10 \mathrm{~mL})$ was stirred at room temperature for $2 \mathrm{~h}$. The reaction mixture was evaporated and re-dissolved in dichloromethane (50 $\mathrm{mL})$ before washed with sodium bicarbonate (sat., $20 \mathrm{~mL} \times 3)$, brine $(20 \mathrm{~mL})$ and dried over anhydrous sodium sulfate. The solvent was evaporated, and the product was used directly in the next step. A solution of deprotected 6 (71 mg, $0.108 \mathrm{mmol}$ ), D-desthiobiotin 7 (26 mg, $0.119 \mathrm{mmol}$ ), EDC (18.5 mg, $0.119 \mathrm{mmol}$ ) and 4-dimethylaminopyridine (1 $\mathrm{mg}$, cat.) in $5 \mathrm{~mL}$ of dichloromethane was stirred at room temperature overnight. The reaction mixture was diluted with $50 \mathrm{~mL}$ of dichloromethane, then washed with $1 \mathrm{M}$ hydrochloric acid $(20 \mathrm{~mL}$ $\times 3$ ), sodium bicarbonate (sat., $20 \mathrm{~mL}$ ), brine (20 mL) and dried over anhydrous sodium sulfate. The solvent was removed in vacuo and the crude was purified by flash chromatography (silica, methanol in dichloromethane $0-5 \%$ ) to afford the product as a colorless oil (75 mg, 82\%). ${ }^{1} \mathrm{H}$ NMR (400 MHz, $\left.\mathrm{CDCl}_{3}\right) \delta(\mathrm{ppm}): 6.48(\mathrm{~s}, 1 \mathrm{H}), 6.27(\mathrm{~s}, 1 \mathrm{H})$, $5.33(\mathrm{~s}, 1 \mathrm{H}), 4.83-4.77(\mathrm{~m}, 1 \mathrm{H}), 4.68(\mathrm{~s}, 1 \mathrm{H}), 4.02(\mathrm{~s}, 1 \mathrm{H}), 3.84-3.81(\mathrm{~m}, 1 \mathrm{H}), 3.68-3.55(\mathrm{~m}$, $13 \mathrm{H}), 3.35-3.32(\mathrm{~m}, 4 \mathrm{H}), 2.24-0.89(\mathrm{~m}, 52 \mathrm{H}), 0.62(\mathrm{~s}, 3 \mathrm{H}) .{ }^{13} \mathrm{C} \mathrm{NMR}\left(100 \mathrm{MHz}, \mathrm{CDCl}_{3}\right) \delta(\mathrm{ppm})$ : 173.6, 172.8, 166.8, 163.4, 76.7, 70.4, 70.4, 70.1, 70.0, 69.8, 56.4, 56.1, 56.0, 53.4, 51.3, 42.7, 41.8, 41.3, $40.3,40.1,37.8,37.6,36.2,35.7,35.5,34.9,34.5,33.6,32.0,31.8,29.5,29.1,29.0,28.8,28.2,26.9,26.4$, 26.2, 26.0, 25.3, 24.2, 23.3, 20.8, 18.4, 15.8, 12.0. HR-MS (ES+): calcd. for $\mathrm{C}_{46} \mathrm{H}_{80} \mathrm{~N}_{4} \mathrm{O}_{8}{ }^{35} \mathrm{Cl}$ 851.5639, found 851.5641. FT-IR (ATR): $v_{\max } 3302,2931,2864,1702,1646,1545,1447,1377,1351,1323$, $1284,1253,1194,1106,1001 \mathrm{~cm}^{-1}$. 


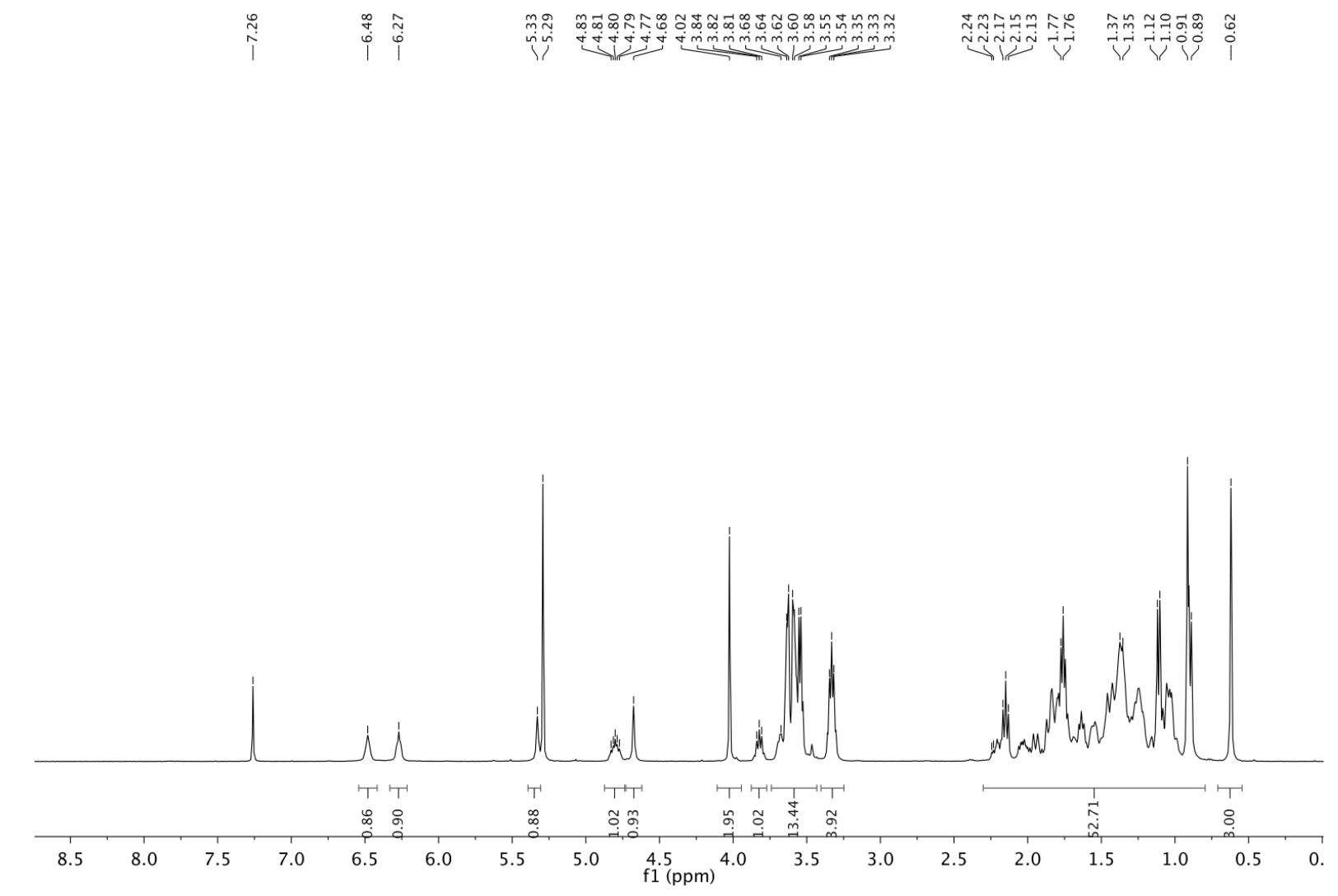

Figure S7. ${ }^{1} \mathrm{H}$ NMR spectrum of compound 8.
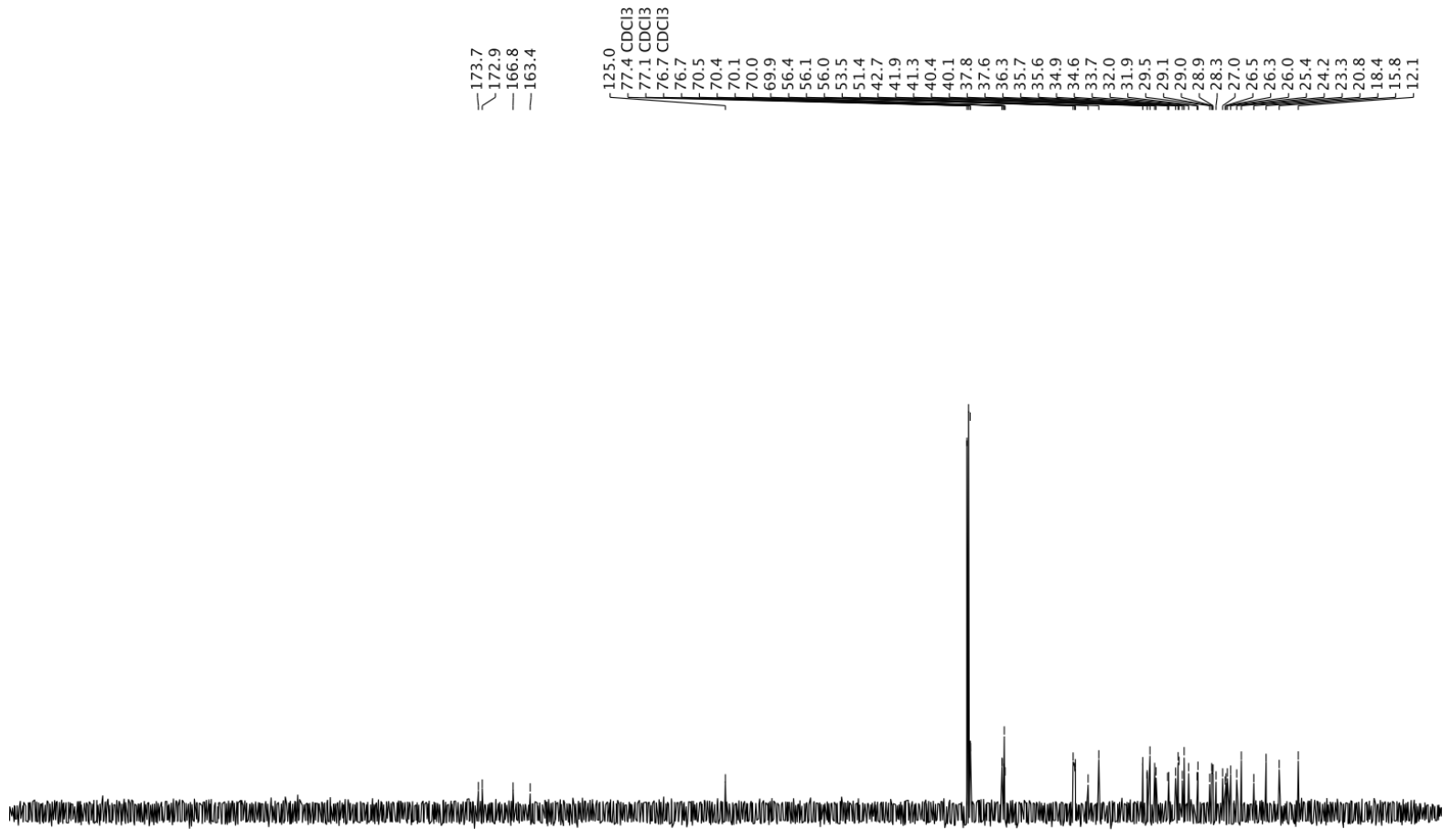

$\begin{array}{lllllllllllllllllllllllllllll}260 & 250 & 240 & 230 & 220 & 210 & 200 & 190 & 180 & 170 & 160 & 150 & 140 & \begin{array}{l}130 \\ \mathrm{f} 1\end{array}(\mathrm{ppm}) & 120 & 110 & 100 & 90 & 80 & 70 & 60 & 50 & 40 & 30 & 20 & 10 & 0 & -10\end{array}$

Figure S8. ${ }^{13} \mathrm{C}$ NMR spectrum of compound 8. 


\section{Compound 9}<smiles>CC(=NO)c1cccc(C(C)=NO)n1</smiles>

Compound 9 has been previously described. ${ }^{3,4}$ A solution of 2,6-diacetylpyridine (100 mg, 0.613 mmol), hydroxylamine (104 mg, $1.53 \mathrm{mmol})$ and sodium hydroxide $(61.2 \mathrm{mg}, 1.533 \mathrm{mmol})$ in water/methanol:1/1 was refluxed overnight. The crude was filtered and recrystallized in methanol to afford a white solid as product (60 mg, 50\%). ${ }^{1} \mathrm{H}$ NMR (400 MHz, DMSO-d 6 ) $\delta(\mathrm{ppm}): 11.77(\mathrm{~s}, 2 \mathrm{H})$, 8.08-8.01 (m, 3H), $2.50(\mathrm{~s}, 6 \mathrm{H}) .{ }^{13} \mathrm{C} \mathrm{NMR}\left(100 \mathrm{MHz}, \mathrm{DMSO}-\mathrm{d}_{6}\right) \delta(\mathrm{ppm}): 154.3,153.5,136.9,119.2$, 10.2. MS (ES+): $194.2\left(\mathrm{M}-\mathrm{H}^{+}\right)$. 


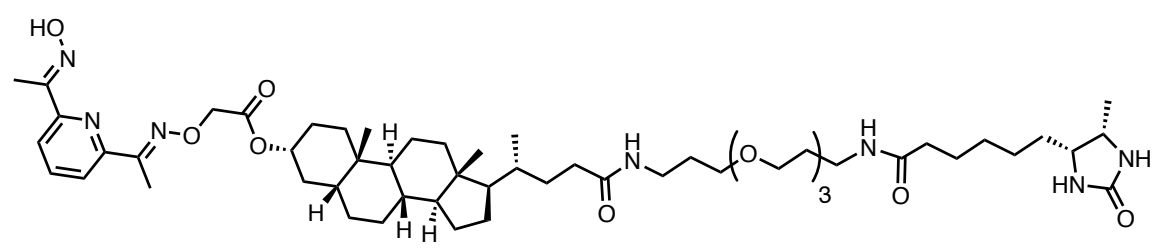

A solution of compound 9 (19 $\mathrm{mg}, 0.099 \mathrm{mmol}$ ) and potassium carbonate (2 $\mathrm{mg}, 0.164$ mmol) in dimethylformamide (1 mL) was stirred at room temperature for $15 \mathrm{~min}$ and was added a solution of compound 8 (28 $\mathrm{mg}, 0.033 \mathrm{mmol}$ ) in dimethylformamide (1 mL). The reaction mixture was stirred at room temperature overnight. The reaction mixture was diluted with $50 \mathrm{~mL}$ of ethyl acetate and washed with hydrochloric acid $(1 \mathrm{M}, 5 \mathrm{~mL})$, lithium chloride (5\% aq., $5 \mathrm{~mL} \times 5$ ), sodium bicarbonate (sat., $5 \mathrm{~mL}$ ), brine $(5 \mathrm{~mL})$ and dried over anhydrous sodium sulfate. The solvent was removed and the product as a colorless oil (19 mg, 63\%). ${ }^{1} \mathrm{H}$ NMR $\left(400 \mathrm{MHz}, \mathrm{CDCl}_{3}\right) \delta(\mathrm{ppm}): 6.48(\mathrm{~s}, 1 \mathrm{H}), 6.27(\mathrm{~s}, 1 \mathrm{H}), 5.33$ (s, $1 \mathrm{H}), 4.83-4.77(\mathrm{~m}, 1 \mathrm{H}), 4.68(\mathrm{~s}, 1 \mathrm{H}), 4.02(\mathrm{~s}, 1 \mathrm{H}), 3.84-3.81(\mathrm{~m}, 1 \mathrm{H}), 3.68-3.55(\mathrm{~m}, 13 \mathrm{H})$, $3.35-3.32(\mathrm{~m}, 4 \mathrm{H}), 2.24-0.89(\mathrm{~m}, 52 \mathrm{H}), 0.62(\mathrm{~s}, 3 \mathrm{H}) .{ }^{13} \mathrm{C} \mathrm{NMR}\left(100 \mathrm{MHz}, \mathrm{CDCl}_{3}\right) \delta(\mathrm{ppm})$ : 173.6, 172.8, 76.7, 70.4, 70.4, 70.1, 70.0, 69.8, 56.4, 56.1, 56.0, 53.4, 51.3, 42.7, 41.8, 41.3, 40.3, 40.1, $37.8,37.6,36.2,35.7,35.5,34.9,34.5,33.6,32.0,31.8,29.5$, 29.1, 29.0, 28.8, 28.2 26. 26. 26.4, 26.2, 26.0, 25.3, 24.2, 23.3, 20.8, 18.4, 15.8, 12.0. HR-MS (ES-) calcd. for $\mathrm{C}_{55} \mathrm{H}_{89} \mathrm{~N}_{7} \mathrm{O}_{10}$ : 1007.6671, found 1007.6661. FT-IR (ATR): $v_{\max } 3302,2931,2864,1702,1646,1545,1447,1377,1351,1323,1284$, $1253,1194,1106,1001 \mathrm{~cm}^{-1}$. 


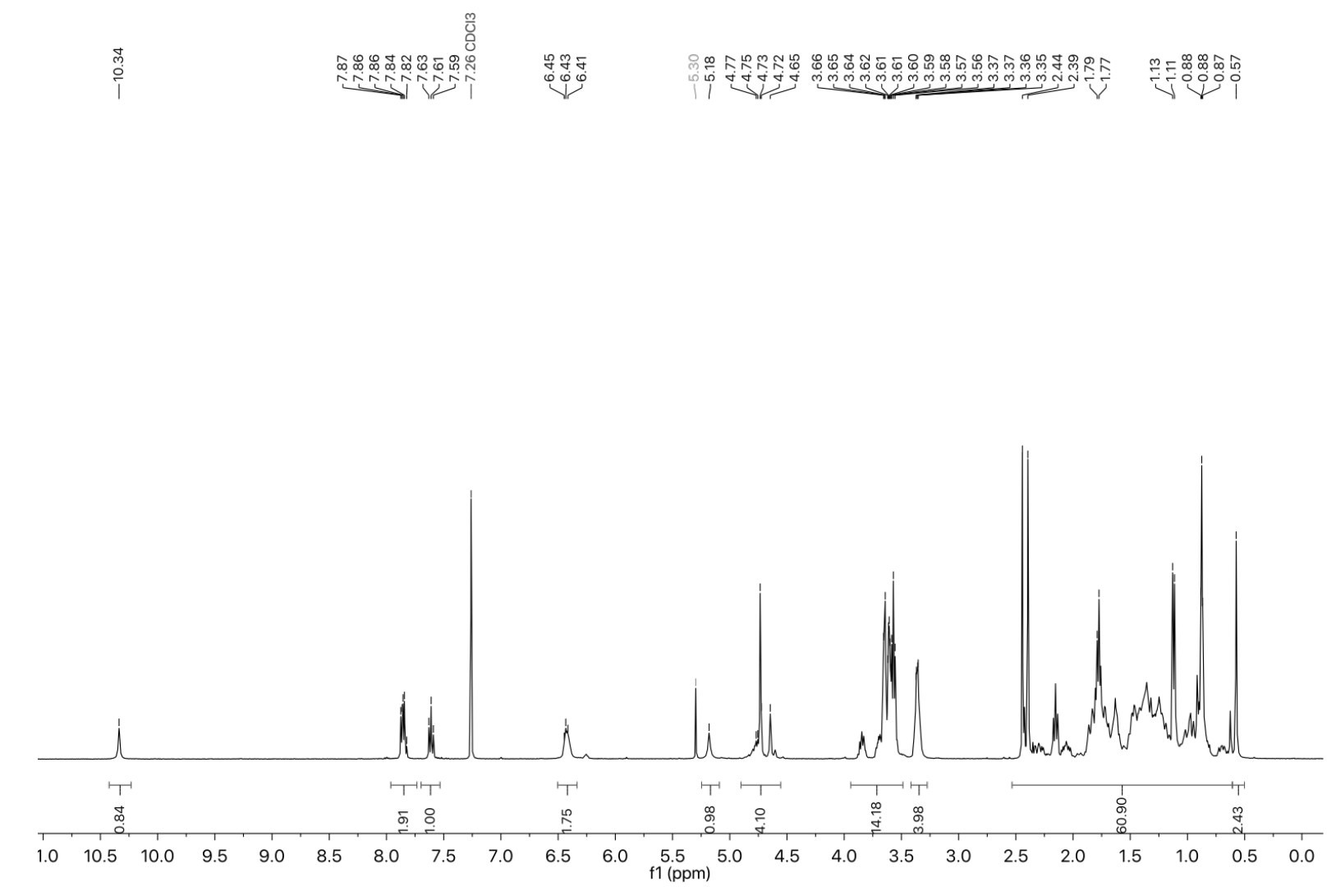

Figure S9. ${ }^{1} \mathrm{H}$ NMR spectrum of desthiobiotin transducer 1.

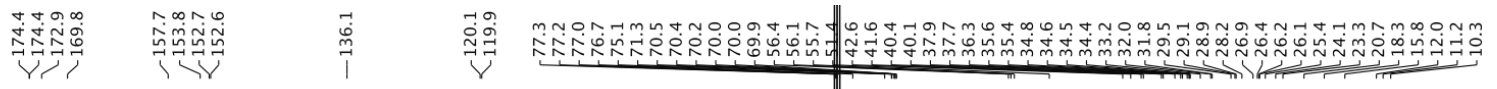

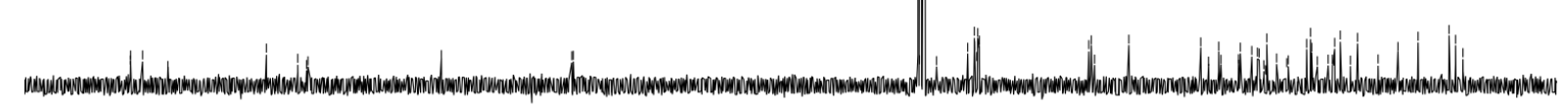

$\begin{array}{llllllllllllllllll}180 & 170 & 160 & 150 & 140 & 130 & 120 & 110 & \underset{\mathrm{f} 1(\mathrm{ppm})}{90} & 80 & 70 & 60 & 50 & 40 & 30 & 20 & 10 & 0\end{array}$

Figure S10. ${ }^{13} \mathrm{C}$ NMR spectrum of desthiobiotin transducer $\mathbf{1}$. 


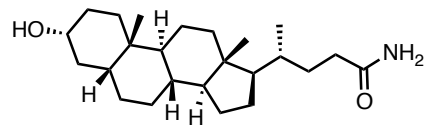

Compound 11 has been previously described. ${ }^{5}$ To a solution of lithocholic acid $(3.0 \mathrm{~g}, 7.97$ mmol) and triethylamine $(1.6 \mathrm{~mL}, 11.5 \mathrm{mmol})$ in tetrahydrofuran was added ethyl chloroformate $(2 \mathrm{~mL}, 21.0 \mathrm{mmol})$ with external cooling. The reaction was further stirred at room temperature for $15 \mathrm{~min}$. Cold concentrated ammonium hydroxide was added with external cooling until $\mathrm{pH}$ is basic. The precipitate was filtered, washed with cold water, and dried in vacuo to afford the product as a white solid (3.0 g, quant.). ${ }^{1} \mathrm{H}$ NMR $\left(400 \mathrm{MHz}, \mathrm{DMSO}-\mathrm{d}_{6}\right) \delta(\mathrm{ppm}): 7.22(\mathrm{br}, 2 \mathrm{H}), 6.64(\mathrm{br}, 1 \mathrm{H}), 3.40-3.33(\mathrm{~m}, 1 \mathrm{H}), 2.09-0.87(\mathrm{~m}$, 34H), 0.61 (s, 3H). HR-MS (MS-): calcd. for $\mathrm{C}_{24} \mathrm{H}_{41} \mathrm{NO}_{2}: 375.3137$, found: 375.3142 . FT-IR (ATR): $v_{\max } 3379,3214,2930,2863,1665,1626,1446,1407,1377,1334,1303,1252,1189,1167,1088,1069$, $1044 \mathrm{~cm}^{-1}$.

\section{Compound 12}

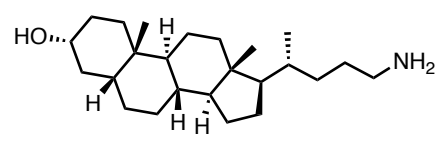

Compound 12 has been previously described. ${ }^{5}$ To a solution of lithium aluminum hydride in tetrahydrofuran (1M, $20 \mathrm{~mL}$ ) was added a solution of compound $\mathbf{1 1}(2.5 \mathrm{~g}, 6.65 \mathrm{mmol})$ in tetrahydrofuran $(100 \mathrm{~mL})$, and the reaction mixture was refluxed overnight. The reaction mixture was diluted with $80 \mathrm{~mL}$ of ethyl acetate, and was added water $(0.76 \mathrm{~mL})$, sodium hydroxide (15\% aq., $0.76 \mathrm{~mL})$, water $(2.28 \mathrm{~mL})$, in this order respectively and stirred for $15 \mathrm{~min}$. Anhydrous magnesium sulfate was added and the reaction mixture was stirred for further $15 \mathrm{~min}$. The product was filtered, washed with cold water, dried in vacuo to afford the product as a pale yellow solid $(2.0 \mathrm{~g}, 83 \%) .{ }^{1} \mathrm{H}$ NMR (400 MHz, DMSO- $\left.\mathrm{d}_{6}\right) \delta$ $(\mathrm{ppm}): 3.65-3.60(\mathrm{~m}, 1 \mathrm{H}), 2.04-0.92(\mathrm{~m}, 37 \mathrm{H}), 0.64(\mathrm{~s}, 3 \mathrm{H})$. HR-MS (MS+): calcd. for 
$\mathrm{C}_{24} \mathrm{H}_{43} \mathrm{NO}$ : 361.3345, found: 361.3341. FT-IR (ATR): $v_{\max } 2935,2860,1579,1564,1548,1461$, $1446,1375,1365,1067,1057,1013 \mathrm{~cm}^{-1}$.

Biotin derivative $\mathbf{1 0}$

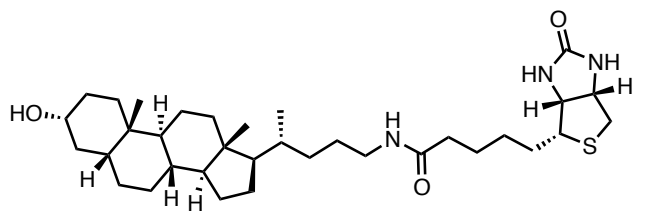

A reaction mixture of compound $12(50.0 \mathrm{mg}, 0.138 \mathrm{mmol})$, D-biotin (30.5 $\mathrm{mg}, 0.124$ mmol), EDC (39.7 mg, $0.207 \mathrm{mmol})$, 4-dimethylaminopyridine (1 $\mathrm{mg}$, cat.) in dimethylformamide $(2 \mathrm{~mL})$ was stirred at room temperature overnight. The reaction mixture was diluted with $50 \mathrm{~mL}$ of ethyl acetate, washed with hydrochloric acid (1 M, 5 $\mathrm{mL}$ ), lithium chloride ( $5 \%$ aq., $5 \mathrm{~mL} \times 5$ ), sodium bicarbonate (sat., $5 \mathrm{~mL}$ ), brine $(5 \mathrm{~mL})$, and dried over anhydrous sodium sulfate. After evaporation of solvent, the crude was purified by flash chromatography (basic alumina, methanol in dichloromethane: $0-10 \%$ ) to afford the product as a colorless gel (39 mg, 54\%). ${ }^{1} \mathrm{H}$ NMR $\left(400 \mathrm{MHz}, \mathrm{CDCl}_{3}\right) \delta(\mathrm{ppm})$ : $6.30(\mathrm{~s}, 1 \mathrm{H}), 6.00\left(\mathrm{t},{ }^{3} J=5.8 \mathrm{~Hz}, 1 \mathrm{H}\right), 5.52(\mathrm{~s}, 1 \mathrm{H}), 4.50\left(\mathrm{dd},{ }^{3} J=7.4,4.9 \mathrm{~Hz}, 1 \mathrm{H}\right), 4.30\left(\mathrm{dd},{ }^{3} J=7.4\right.$, $4.9 \mathrm{~Hz}, 2 \mathrm{H}), 3.64-3.58(\mathrm{~m}, 1 \mathrm{H}), 3.25-3.12(\mathrm{~m}, 2 \mathrm{H}), 2.91\left(\mathrm{dd},{ }^{3} J=12.8,4.9 \mathrm{~Hz}, 1 \mathrm{H}\right), 2.74\left(\mathrm{~d},{ }^{3} J=\right.$ $12.8 \mathrm{~Hz}, 1 \mathrm{H}), 2.19\left(\mathrm{t},{ }^{3} J=7.4 \mathrm{~Hz}, 2 \mathrm{H}\right), 1.96-0.89(\mathrm{~m}, 41 \mathrm{H}), 0.63(\mathrm{~s}, 3 \mathrm{H}) .{ }^{13} \mathrm{C}$ NMR $(100 \mathrm{MHz}$, $\left.\mathrm{CDCl}_{3}\right) \delta 173.0,163.7,77.3,77.0,76.7,71.7,61.8,60.1,56.5,56.0,55.5,42.6,42.0,40.6,40.4,40.2$, 40.0, 36.4, 36.1, 35.8, 35.4, 35.3, 34.5, 33.1, 30.5, 28.3, 28.2, 28.1, 27.1, 26.4, 26.1, 25.7, 24.2, 23.3, 20.8, 18.6, 12.0. HR-MS (MS+): calcd for $\mathrm{C}_{34} \mathrm{H}_{57} \mathrm{~N}_{3} \mathrm{O}_{3} \mathrm{~S}: 587.4121$, found 587.4112. FT-IR (ATR): $v_{\max }$ $3271,2925,2860,1696,1643,1551,1449,1375,1365,1330,1306,1262,1214,1163,1068,1037 \mathrm{~cm}^{-}$ 1. 


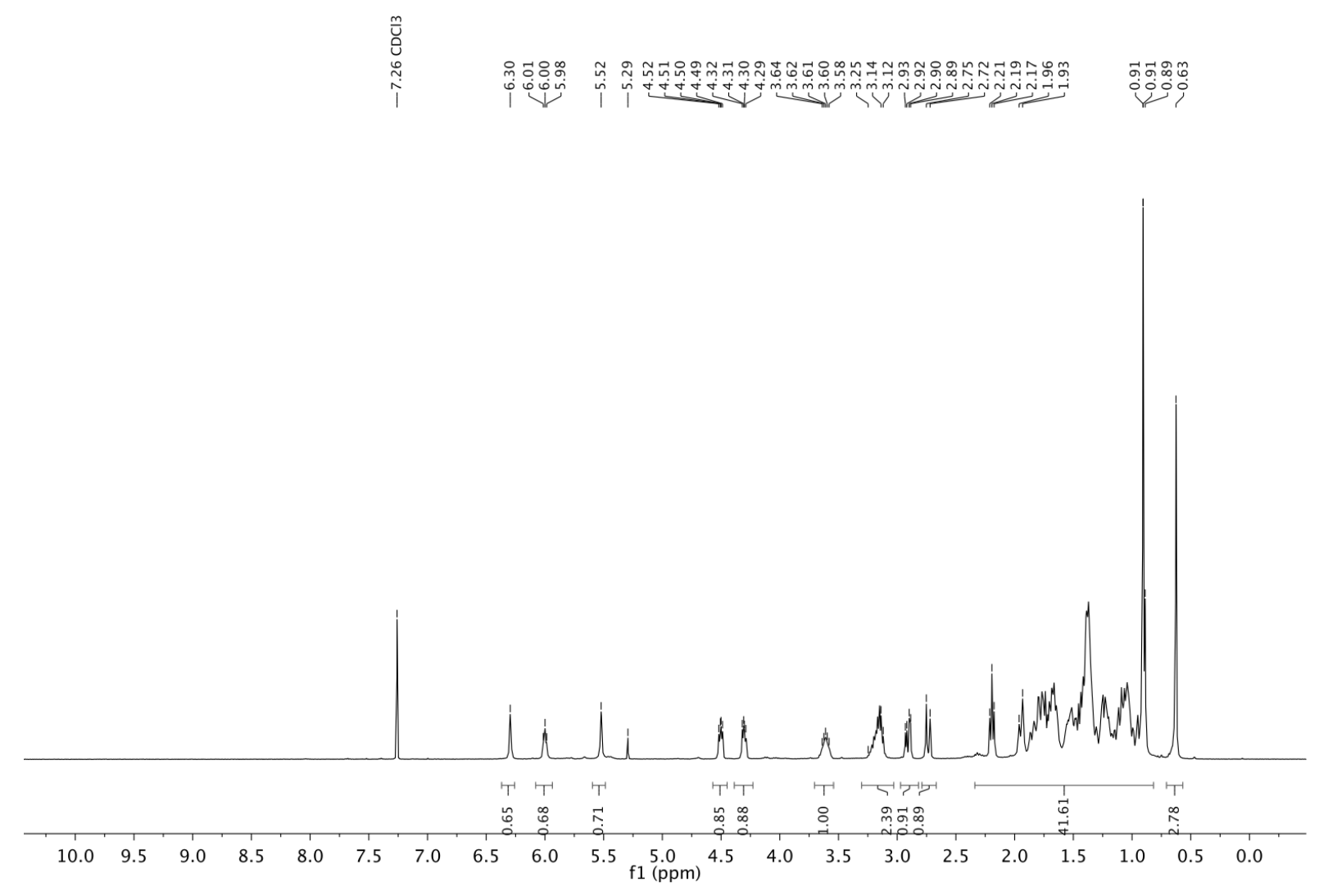

Figure S11. ${ }^{1} \mathrm{H}$ NMR spectrum of biotin derivative $\mathbf{1 0 .}$

$\stackrel{0}{\stackrel{\infty}{n}} \stackrel{\substack{\hat{n} \\ 1}}{1}$

\begin{tabular}{l}
$m$ \\
$\bar{U}$ \\
\hdashline \\
\hdashline
\end{tabular}

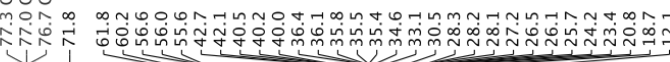

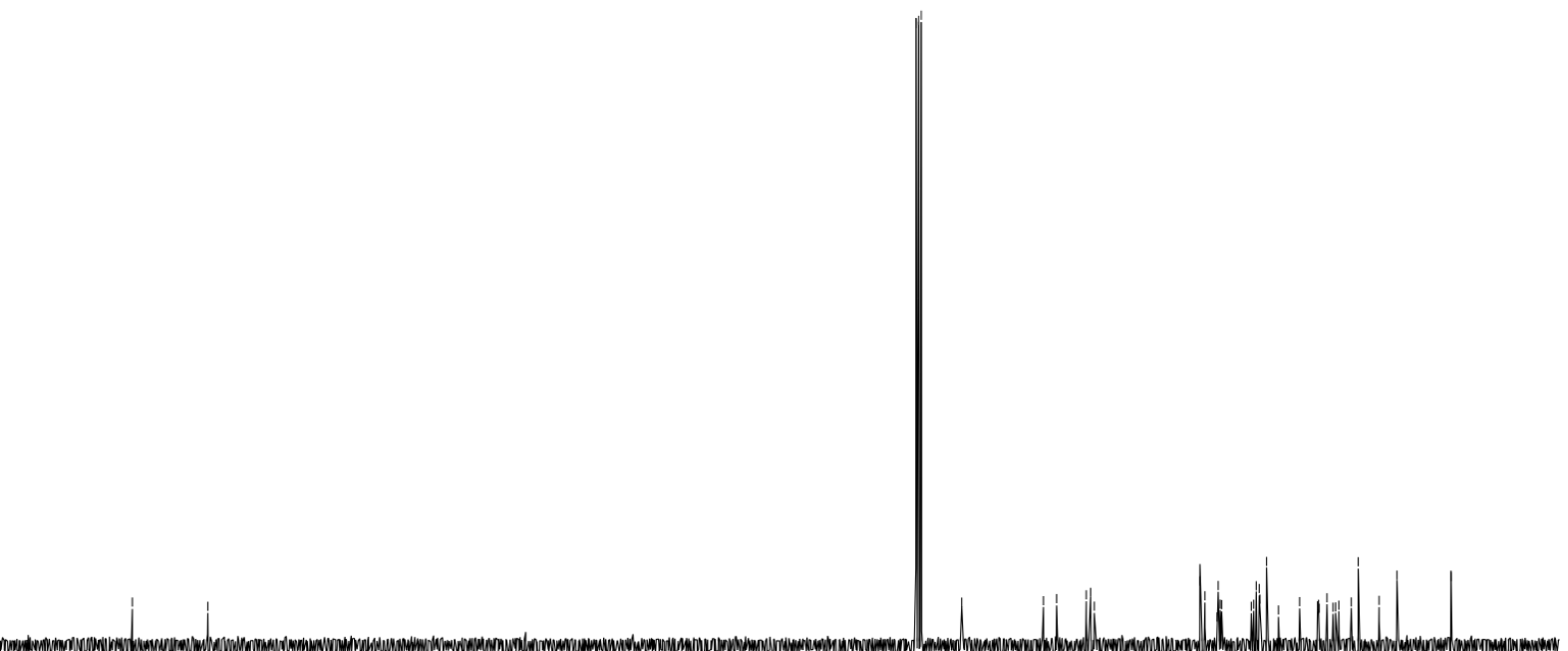

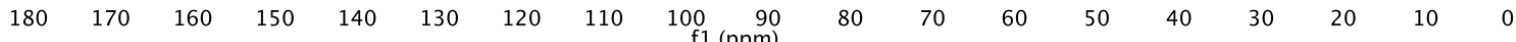

Figure S12. ${ }^{13} \mathrm{C}$ NMR spectrum of biotin derivative $\mathbf{1 0}$. 


\section{Vesicles experiments}

\section{General protocol for vesicles preparation}

To a $1.5 \mathrm{~mL}$ microcentrifuge tube was added chloroform solutions of lipids (DOPC/DOPE in a 3:2 ratio) in order to obtain final lipid concentrations of $1 \mathrm{mM}$ in $3.5 \mathrm{~mL}$ (final elution volume). The solvent was evaporated using a dry nitrogen steam and dried under high vacuum for at least $2 \mathrm{~h}$ to yield a thin lipid film. To the microcentrifuge containing the lipids was added $0.5 \mathrm{~mL}$ of $25 \mathrm{mM}$ HEPES $150 \mathrm{mM} \mathrm{NaCl}$ buffer at $\mathrm{pH}$ 7, as well as stock solutions of ester substrate and zinc chloride as appropriate to reach final concentrations of $250 \mu \mathrm{M}$. After swelling for $1 \mathrm{~min}$, the suspension was subjected to 5 cycles of freezethaw using liquid nitrogen and $35{ }^{\circ} \mathrm{C}$ water bath. The suspension was extruded for 19 times through a $200 \mathrm{~nm}$ polycarbonate filter in an extruder apparatus, and then the vesicles were separated by a bulk solution using prepacked SEC columns eluting with the same HEPES buffer at $\mathrm{pH}$ 7. Vesicles suspensions can be further diluted using HEPES buffer to $0.1 \mathrm{mM}$ lipid concentration.

\section{Fluorescence Measurements}

Substrate $\mathbf{2}$ hydrolyses slowly in water, and there is some batch to batch variation in the background rate of hydrolysis inside vesicles, so a separate control experiment was carried out for each kinetic run. For each fluorescence experiment, a sample of the same batch of vesicles containing $\mathbf{2}$ was monitored to measure the background hydrolysis rate in the absence of any catalysis. These data were subtracted from the fluorescence data recorded in the catalysis experiment to remove the effects of background hydrolysis. At the end of the experiment, $50 \mu \mathrm{L}$ of $5 \%$ Triton $\mathrm{X}-100$ and $1 \mathrm{M} \mathrm{NaOH}$ was added to lyse the vesicles and hydrolyze all of the remaining substrate 2 . The emission measured at this end point was used to normalize the data taking into account of the dilution factor.

ON State. To a $1 \mathrm{~mL}$ fluorescence cuvette was added $800 \mu \mathrm{L}$ of $0.1 \mathrm{mM}$ vesicles described above. $1 \mathrm{mM} 1$ solution in DMSO was added to the vesicles suspension to reach $10 \mathrm{~mol} \%$ loading of 1 relative to lipids.

OFF State. NeutrAvidin•1 1:4 complex solution was prepared by adding 4 eq. of 1 (1 mM DMSO solution) to $16.7 \mu \mathrm{M}$ protein solution in HEPES buffer. To a $1 \mathrm{~mL}$ fluorescence cuvette was added $800 \mu \mathrm{L}$ of $16.7 \mu \mathrm{M}$ NeutrAvidin•1 1:4 complex solution in HEPES buffer. $1 \mathrm{mM} 200 \mathrm{~nm}$ DOPC/DOPE:3/2 vesicles containing $250 \mu \mathrm{M}$ substrate 2 and 250 
$\mu \mathrm{M}$ zinc chloride in $25 \mathrm{mM}$ HEPES $150 \mathrm{mM} \mathrm{NaCl}$ was added to the cuvette to reach a final lipid concentration of $0.1 \mathrm{mM}$.

ON-OFF Switching. To a $1 \mathrm{~mL}$ fluorescence cuvette was added $800 \mu \mathrm{L}$ of $0.01 \mathrm{mM} 200$ nm DOPC/DOPE:3/2 vesicles containing $250 \mu \mathrm{M}$ substrate 2 and $250 \mu \mathrm{M}$ zinc chloride in $25 \mathrm{mM}$ HEPES $150 \mathrm{mM} \mathrm{NaCl} 0.1 \mathrm{mM}$ Transducer 1 solution in DMSO was added to the vesicles suspension using Hamilton syringes to reach 10 mol\% loading of 1 relative to lipids. After 100 minutes, $83.3 \mu \mathrm{M}$ NeutrAvidin solution in HEPES buffer was added to reach a final protein concentration of $2 \mu \mathrm{M}$ ( 2 eq. relative to $\mathbf{1}$ ).

Attempted OFF-ON Switching with Biotin. To the OFF State vesicles described above was added $1 \mathrm{mM}$ biotin solution in HEPES buffer to reach $66.8 \mu \mathrm{M}$ final concentration of biotin (4 eq. relative to NeutrAvidin).

OFF-ON Switching with Biotinylated Vesicles. To the OFF State vesicles described above was added $1 \mathrm{mM}$ (lipid concentration) of biotinylated vesicles to reach $66.8 \mu \mathrm{M}$ of 10 in final bulk concentration, 4 eq. relative to NeutrAvidin. Biotinylated vesicles were prepared in the same manner with 10 mol\% of biotin derivate 10 in the chloroform solution of lipids. Flocculation occurs in this experiment, but the timescale is hours and is variable. The results presented are for at least three repetitions of the experiment before flocculation occurred.

\section{References}

(1) Dahmani, I.; Ludwig, K.; Chiantia, S. Influenza A Matrix Protein M1 Induces Lipid Membrane Deformation via Protein Multimerization. Biosci. Rep. 2019, 39(8), BSR20191024. https://doi.org/10.1042/BSR20191024.

(2) Langton, M. J.; Keymeulen, F.; Ciaccia, M.; Williams, N. H.; Hunter, C. A. Controlled Membrane Translocation Provides a Mechanism for Signal Transduction and Amplification. Nat. Chem. 2017, 9 (5), 426-430. https://doi.org/10.1038/nchem.2678.

(3) Aakeröy, C. B.; Sinha, A. S. Synthesis of Ketoximes via a Solvent-Assisted and Robust Mechanochemical Pathway. RSC Adv. 2013, 3 (22), 8168-8171. https://doi.org/10.1039/C3RA40585K.

(4) Glynn, C. W.; Turnbull, M. M. Complexes of 2,6-Diacetylpyridine Dioxime (DapdoH2). Crystal Structures of $[\mathrm{M}(\mathrm{DapdoH} 2) 2](\mathrm{ClO} 4) 2(\mathrm{M}=\mathrm{Cu}$ and $\mathrm{Mn}) .10$.

(5) Joachimiak, R.; Piasecka, M.; Paryzek, Z. Synthesis of Novel Amide-Linked Dimers of Lithocholic Acid. J. Chem. Res. 2008, 2008 (5), 260-265. https://doi.org/10.3184/030823408X318325. 